in the linkages with the metal. This relation seems to agree with those on planar complexes. ${ }^{4}$

As to the band at $\nu 110 \times 10^{13} / \mathrm{sec}$, which may be ascribed to transitions in the cyclopentadienyl-rings in co-ordination with the metal, ${ }^{5}$ absorption with electric vector along the rings is slightly hypsochromic to that perpendicular to the above. Such tendency is different from that for $\pi$-bands of benzene rings ${ }^{\mathbf{a}}$ and for specific bands of $\pi$-electron systems in co-ordination with metal atoms; ${ }^{4}$ for both the bands absorption is far bathochromic along the $\pi$-electron systems to that perpendicular to the above, ${ }^{4,6}$ Therefore, it is supposed that the electronic state of the cyclopentadienyl-rings in dicyclopentadienyl-iron differs from that of the $\pi$-electron systems in complexes of a usual type as well as from that of benzene derivatives. Thus as far as dichroism is concerned, dicyclopentadienyl-iron seems to exhibit very little aromatic property. ${ }^{7}$ Such behavior of this compound may be understood qualitatively, assuming that the $\pi$ electrons would be attracted toward the iron atom to form co-ordinate bonds.

The authors wish to express their sincere thanks to Mr. C. Holstein of Firm C. Holstein for a sample of cyclopentadiene, and to Miss I. Föppl (Dipl. Chem.) for her kind interest and valuable help in this work.

1 R. Tsuchida and M. Kobayashi, The Colours and the Structures of Metallic Compounds (Zoshindo, Osaka, 1944), p. 180

2 E. O. Fischer and W. Pfab, Z. Naturforsch., 7b, 377 (1952); J. D. Dunitz and L. E. Orgel, Nature 171, 121 (1953); P. F. Eiland and R. Pepinsky, J. Am. Chem. Soc. 74, 4971 (1952).

3 The $a$ and $b$ absorptions denote absorptions with electric vector along and perpendicular to the $a$ plane of the crystal.

"S. Yamada and R. Tsuchida, Bull. Chem. Soc. (Japan) 26, 489 (1953). 5 Such a kind of band was previously named "specific band." See R. Tsuchida and M. Kobayashi, Bull. Chem. Soc. (Japan) 13, 476 (1938).

6 Tsuchida, Kobayashi, and Nakamoto, J. Chem. Soc. (Japan) 70, 12 (1949); Scheibe, Hartwig, and Müller, Z. Elektrochem. 49, 372 (1943)

7 E. O. Fischer and R. Jira, Z. Naturforsch. 8b, 1 (1953).

\section{Infrared Evidence for Collagen Structures}

G. B. B. M. Sutherland, K. Nolen Tanner,* and D. L. Wood The Harrison M. Randall Laboratory of Physics, University of Michigan, Ann Arbor, Michigan (Received July 2, 1954)

A NEW structure for collagen has recently been proposed by A Crick $^{1}$ consisting of two polypeptide chains wound helically round a common axis. This structure is put forward for the more ordered "interbands" which Bear" has suggested contain predominantly the shorter amino acids. Since this model was based solely on $x$-ray analysis, it is important to consider to what extent infrared data are consistent with the new model.

We have examined the dichroism of collagen (kangaroo-tail tendon) and of oriented gelatin in the range $5000-600 \mathrm{~cm}^{-1}$. Our results are summarized in the second column of Table I. Absorption bands which are more intense when the electric vector is parallel to the fiber axis (or direction of extension, in the case of gelatin) are said to show parallel dichroism (11), and those which are more intense when the electric vector is perpendicular to the axis are said to show perpendicular dichroism (L). Our results agree qualitatively with those reported by Ambrose and Elliott ${ }^{3}$ but are more extensive in that we have investigated a very important band at $650 \mathrm{~cm}^{-1}$.

If the Crick model is correct, then the majority of NH bonds lie in planes perpendicular to the fiber axis. Half of the $\mathrm{CO}$ bands also lie in these planes, but the other half of the bonds are not perpendicular to the fiber axis. Thus the NH-stretching frequency near $3300 \mathrm{~cm}^{-1}$ should show perpendicular dichroism. The COstretching frequency near $1650 \mathrm{~cm}^{-1}$ may also be expected to show perpendicular dichroism but not so marked as that of the 3300 $\mathrm{cm}^{-1}$ band. Both bands do indeed show perpendicular dichroism but the dichroic ratio appears to be higher for the $\mathrm{CO}$ than for the $\mathrm{NH}$ frequency in contradiction to the values predicted from the Crick model.

A much more serious contradiction occurs in the dichroism of the out-of-plane NH-deformation frequency ${ }^{4}$ at $650 \mathrm{~cm}^{-1}$. This
TABLE I. Dichroism of infrared bands of collagen.

\begin{tabular}{clcl}
\hline $\begin{array}{c}\text { Band center } \\
\text { in cm }\end{array}$ & $\begin{array}{c}\text { Observed } \\
\text { dichroism }\end{array}$ & $\begin{array}{c}\text { Predicted } \\
\text { dichroism } \\
\text { on Crick } \\
\text { model }\end{array}$ & \multicolumn{1}{c}{ Interpretation } \\
\hline 650 & I(weak) & 11 & $\begin{array}{l}\text { NH deformation out } \\
\text { of plane }\end{array}$ \\
1550 & II (weak) & $\perp$ & $\begin{array}{l}\text { NH deformation in } \\
\text { plane }+\mathrm{C}-\mathrm{N} \text { stretch } \\
1650\end{array}$ \\
3300 & $\perp$ & $\perp$ & CO stretching \\
4590 & $\perp$ & $\perp$ & NH stretching \\
4850 & $\perp$ & $?$ & $?$ \\
\hline
\end{tabular}

should undoubtedly show strong parallel dichroism. In fact, it shows very weak perpendicular dichroism or none at all. A further contradiction occurs when we consider the $1550 \mathrm{~cm}^{-1}$ band which is now generally accepted to be a nonseparable fundamental involving a deformation motion of the $\mathrm{NH}$ band in the plane of the peptide link together with a stretching motion of the peptide $\mathrm{C}-\mathrm{N}$ link. ${ }^{5}$ Since this mode of vibration is entirely in the plane of the eight-membered ring (proposed by Crick) it should show marked perpendicular dichroism. It exhibits weak parallel dichroism. Furthermore, the combination band near $4850 \mathrm{~cm}^{-1}$ (which is generally assumed to be the sum of $1550 \mathrm{~cm}^{-1}$ and $3300 \mathrm{~cm}^{-1}$ ) should also show perpendicular dichroism since both these vibrations take place in planes perpendicular to the fiber axis. It exhibits a definite parallel dichroism.

It would seem therefore that the Crick model is incompatible with the observed dichroism of the infrared spectrum of collagen or oriented gelatin.

The work reported here was supported in part by a grant from the Rockefeller Foundation which is gratefully acknowledged.

* Present address: Naval Ordnance Laboratory, Corona, California.

${ }^{1}$ F. H. C. Crick, J. Chem. Phys. 22, 347 (1954)

2 R. S. Bear, Advances in Protein Chem. 7, 69-160 (1952). 3 E. J. Ambrose and A. Elliott, Proc. Roy. Soc. (London) A206, 206

${ }_{4 \mathrm{H}}^{(1951)}$ K. Kessler and G. B. B. M. Sutherland, J. Chem. Phys, 21, 570 (1953). 5 W. C. Price and R. D. B. Fraser, Proc. Roy. Soc. (London) B141, 66

\section{Methyl Affinities of Aromatic Compounds}

M. LEVy AND M. SzWARC

College of Forestry, State University of New York, Syracuse 10. New York

(Received June 17, 1954)

$\mathrm{T}$ is well known that radicals or free atoms may add to olefinic compounds thus producing new radicals, such a reaction being exemplified by the equation

$$
R+\mathrm{CH}_{2}: \mathrm{CH}_{2} \rightarrow R \cdot \mathrm{CH}_{2} \cdot \mathrm{CH}_{2} \text {. }
$$

A considerable volume of evidence, ${ }^{1-5}$ accumulated during the last few years, indicates that a similar reaction may take place during an interaction between radicals and an aromatic compound, e.g.,

$$
R+\mathrm{C}_{6} \mathrm{H}_{6} \rightarrow R \cdot \mathrm{C}_{6} \mathrm{H}_{6} \text {. }
$$

Our recent studies ${ }^{6}$ have shown that reaction (2) takes place indeed in the interaction between methyl radicals and benzene. The continuation of these investigations led us to a method by which one can determine quantitatively the relative ability with which an aromatic compound captures methyl radicals. We propose the name "methyl affinity" for this particular property of aromatic compounds, and in this communication we are reporting the values of the relative methyl affinities for a number of aromatic compounds.

Our method of determining the methyl affinities is as follows. Methyl radicals are generated by the thermal decomposition of 
diacetyl peroxide. ${ }^{*}$ Such a decomposition, carried out in a diluted solution of the peroxide in isooctane, yields carbon dioxide, methane, and ethane in quantities which correspond to the following stoichiometric relation $:^{6,7}$

$$
\left(\mathrm{CH}_{4}+2 \mathrm{C}_{2} \mathrm{H}_{6}\right) / \mathrm{CO}_{2} \approx 1 \text {. }
$$

The addition of an aromatic compound to the solution, decreases the amount of methane formed, without affecting the amount of carbon dioxide formed in the decomposition. It seems, therefore, that the following two competing reactions occur in the latter systems:

$$
\begin{aligned}
& \mathrm{CH}_{3}+\text { iso- } \mathrm{C}_{8} \mathrm{H}_{18} \rightarrow \mathrm{CH}_{4}+\text { iso- } \mathrm{C}_{8} \mathrm{H}_{17} \\
& \mathrm{CH}_{3} \text {-aromatic } \rightarrow \mathrm{CH}_{4} \text {-aromatic. }
\end{aligned}
$$

Denoting by $k_{\mathrm{I}}$ and $k_{\mathrm{II}}$ the bimolecular rate constants of reactions I and II, we conclude that

$$
\begin{aligned}
& \left.k_{\mathrm{II}} / k_{\mathrm{I}}=\text { (the amount of } \mathrm{CH}_{4} \text { lost }\right) /\left(\text { amount of } \mathrm{CH}_{4}\right. \text { formed) } \\
& \qquad\left(x_{8} \mathrm{C}_{18} / x_{\mathrm{aromatic}}\right) \text {, }
\end{aligned}
$$

where (amount of $\mathrm{CH}_{4}$ formed) is the amount of methane actually formed in the reaction, (amount of $\mathrm{CH}_{4}$ lost) is the difference

\begin{tabular}{|c|c|c|c|c|}
\hline $7^{\circ} \mathrm{C}$ & $\begin{array}{l}\text { Mole \% of aromatic } \\
\text { in the solution }\end{array}$ & $\mathrm{CH}_{4} / \mathrm{CO}_{2}$ & $k \amalg \mathrm{I} / k_{\mathrm{I}}$ & $\begin{array}{c}k_{u} \cdot 10^{5} \\
\sec ^{-1}\end{array}$ \\
\hline $\begin{array}{l}65^{\circ} \\
65^{\circ} \\
65^{\circ} \\
85^{\circ} \\
85^{\circ} \\
85^{\circ}\end{array}$ & $\begin{array}{l}25 \% \text { Benzene } \\
50 \% \text { Benzene } \\
75 \% \text { Benzene } \\
25 \% \text { Benzene } \\
50 \% \text { Benzene } \\
75 \% \text { Benzene }\end{array}$ & $\begin{array}{l}0.740 \\
0.605 \\
0.433 \\
0.697 \\
0.582 \\
0.402\end{array}$ & $\begin{array}{l}0.26 \\
0.33 \\
0.29 \\
0.45 \\
0.38 \\
0.33\end{array}$ & $\begin{array}{l}0.84 \\
0.905 \\
0.96 \\
12.5 \\
13.0 \\
13.3\end{array}$ \\
\hline $\begin{array}{l}65^{\circ} \\
65^{\circ} \\
85^{\circ} \\
85^{\circ} \\
85^{\circ}\end{array}$ & $\begin{aligned} 5 \% & \text { Biphenyl } \\
10 \% & \text { Biphenyl } \\
5 \% & \text { Biphenyl } \\
10 \% & \text { Biphenyl } \\
20 \% & \text { Biphenyl }\end{aligned}$ & $\begin{array}{l}0.750 \\
0.682 \\
0.725 \\
0.665 \\
0.550\end{array}$ & $\begin{array}{l}1.4 \\
1.6 \\
2.0 \\
1.9 \\
1.8\end{array}$ & $\begin{array}{c}0.76 \\
0.77 \\
10.4 \\
10.3 \\
9.8\end{array}$ \\
\hline $\begin{array}{l}65^{\circ} \\
65^{\circ} \\
65^{\circ} \\
65^{\circ} \\
85^{\circ} \\
85^{\circ} \\
85^{\circ}\end{array}$ & $\begin{array}{l}5 \% \text { Naphthalene } \\
10 \% \text { Naphthalene } \\
20 \% \text { Naphthalene } \\
20 \% \text { Naphthalene } \\
5 \% \text { Naphthalene } \\
10 \% \text { Naphthalene } \\
20 \% \text { Naphthalene }\end{array}$ & $\begin{array}{l}0.545 \\
0.417 \\
0.253 \\
0.253 \\
0.536 \\
0.412 \\
0.267\end{array}$ & $\begin{array}{r}9.1 \\
9.7 \\
10.3 \\
10.3 \\
9.4 \\
8.5 \\
8.0\end{array}$ & $\begin{array}{l}0.81 \\
0.82 \\
0.87 \\
0.85 \\
11.8 \\
11.0 \\
10.5\end{array}$ \\
\hline $\begin{array}{l}65^{\circ} \\
65^{\circ} \\
65^{\circ} \\
85^{\circ} \\
85^{\circ} \\
85^{\circ} \\
85^{\circ}\end{array}$ & $\begin{array}{l}\text { 1.25\% Phenanthrene } \\
2.5 \% \text { Phenanthrene } \\
5.0 \% \text { Phenanthrene } \\
1.25 \% \text { Phenanthrene } \\
2.5 \% \text { Phenanthrene } \\
5.0 \% \text { Phenanthrene } \\
5.0 \% \text { Phenanthrene }\end{array}$ & $\begin{array}{l}0.668 \\
0.515 \\
0.413 \\
0.650 \\
0.595 \\
0.420 \\
0.420\end{array}$ & $\begin{array}{l}16 \\
22 \\
18 \\
19 \\
14 \\
17 \\
17\end{array}$ & $\begin{array}{l}0.76 \\
0.84 \\
0.83 \\
10.9 \\
10.3 \\
11.3 \\
11.5\end{array}$ \\
\hline $\begin{array}{l}85^{\circ} \\
85^{\circ} \\
85^{\circ}\end{array}$ & $\begin{array}{l}0.25 \% \text { Pyrene } \\
0.75 \% \text { Pyrene } \\
1.00 \% \text { Pyrene }\end{array}$ & $\begin{array}{l}0.727 \\
0.575 \\
0.521\end{array}$ & $\begin{array}{l}41 \\
52 \\
53\end{array}$ & $\begin{array}{l}9.1 \\
9.9 \\
9.9\end{array}$ \\
\hline $\begin{array}{l}65^{\circ} \\
85^{\circ} \\
85^{\circ} \\
85^{\circ} \\
85^{\circ}\end{array}$ & $\begin{array}{ll}0.5 \% & \text { Anthracene } \\
0.125 \% & \text { Anthracene } \\
0.25 \% & \text { Anthracene } \\
0.50 \% & \text { Anthracene } \\
0.50 \% & \text { Anthracene }\end{array}$ & $\begin{array}{l}0.275 \\
0.525 \\
0.442 \\
0.313 \\
0.336\end{array}$ & $\begin{array}{l}385 \\
430 \\
326 \\
310 \\
253\end{array}$ & $\begin{array}{l}0.93 \\
12.7 \\
11.7 \\
11.7 \\
10.4\end{array}$ \\
\hline $\begin{array}{l}65^{\circ} \\
65^{\circ} \\
85^{\circ} \\
85^{\circ} \\
85^{\circ}\end{array}$ & $\begin{array}{l}\text { 20\% Pyridine } \\
30 \% \text { Pyridine } \\
10 \% \text { Pyridine } \\
20 \% \text { Pyridine } \\
30 \% \text { Pyridine }\end{array}$ & $\begin{array}{l}0.615 \\
0.482 \\
0.730 \\
0.615 \\
0.485\end{array}$ & $\begin{array}{l}1.2 \\
1.5 \\
0.9 \\
1.2 \\
1.5\end{array}$ & $\begin{array}{l}1.17 \\
1.41 \\
12.0 \\
12.5 \\
11.5\end{array}$ \\
\hline $\begin{array}{l}65^{\circ} \\
65^{\circ} \\
65^{\circ} \\
85^{\circ} \\
85^{\circ} \\
85^{\circ}\end{array}$ & $\begin{array}{l}10 \% \text { Quinoline } \\
20 \% \text { Quinoline } \\
30 \% \text { Quinoline } \\
10 \% \text { Quinoline } \\
20 \% \text { Quinoline } \\
30 \% \text { Quinoline }\end{array}$ & $\begin{array}{l}0.327 \\
0.195 \\
0.111 \\
0.357 \\
0.211 \\
0.135\end{array}$ & $\begin{array}{l}13.2 \\
12.5 \\
14.4 \\
11.2 \\
11.2 \\
11.5\end{array}$ & $\begin{array}{r}0.99 \\
1.24 \\
1.39 \\
11.8 \\
11.5 \\
11.4\end{array}$ \\
\hline $\begin{array}{l}65^{\circ} \\
85^{\circ} \\
85^{\circ} \\
85^{\circ}\end{array}$ & $\begin{array}{r}5 \% \text { Benzophenone } \\
5 \% \text { Benzophenone } \\
10 \% \text { Benzophenone } \\
20 \% \text { Benzophenone }\end{array}$ & $\begin{array}{l}0.660 \\
0.638 \\
0.550 \\
0.395\end{array}$ & $\begin{array}{l}4.2 \\
4.9 \\
4.1 \\
4.1\end{array}$ & $\begin{array}{l}0.79 \\
10.6 \\
10.4 \\
10.8\end{array}$ \\
\hline $\begin{array}{l}85^{\circ} \\
85^{\circ} \\
85^{\circ}\end{array}$ & $\begin{array}{l}10 \% \text { Diphenyl ether } \\
20 \% \text { Diphenyl ether } \\
30 \% \text { Diphenyl ether }\end{array}$ & $\begin{array}{l}0.725 \\
0.640 \\
0.585\end{array}$ & $\begin{array}{l}0.95 \\
1.0 \\
0.8\end{array}$ & $\begin{array}{l}9.2 \\
8.4 \\
8.2\end{array}$ \\
\hline
\end{tabular}
between the amount of methane formed in the absence of an aromatic compound and in its presence, and $x \mathrm{C}_{8} \mathrm{H}_{18} / x_{\text {arom }}$ is the molar ratio of iso-octane and the aromatic compound in the solu-

TABLE I.
TABLE II. The relative methyl affinities; benzene taken as unity.

\begin{tabular}{lc}
\hline Compound & Relative methyl affinity \\
\hline Benzene & 1 \\
Diphenyl & 5 \\
Naphthalene & 22 \\
Phenanthrene & 42 \\
Pyrene & 125 \\
Anthracene & 820 \\
Pyridine & 3 \\
Quinoline & 29 \\
Benzophenone & 11 \\
Diphenyl ether & 2.5 \\
\hline
\end{tabular}

tion. We suggest that the ratio $k_{\mathrm{II}} / k_{\mathrm{I}}$ may be considered as a measure of the relative methyl affinity of an aromatic compound.

The results of our experiments are listed in Table I. The ratio $\mathrm{CH}_{4} / \mathrm{CO}_{2}$ measures the amount of methane formed in the reaction. The amount of methane "lost" is obtained by subtracting the $\mathrm{CH}_{4} / \mathrm{CO}_{2}$ ratio listed in Table $\mathrm{I}$ from the $\mathrm{CH}_{4} / \mathrm{CO}_{2}$ ratio obtained in the decomposition of diacetyl peroxide proceeding in a pure isooctane. The latter ratio has been found to be 0.805 for $65^{\circ} \mathrm{C}$ and 0.802 for $85^{\circ} \mathrm{C}$.

It is important to notice that the ratio $k_{\mathrm{II}} / k_{\mathrm{I}}$ remain approximately constant when the molar percent of the added aromatic compound is varied by a factor 3-4. This constancy of $k_{\mathrm{II}} / k_{\mathrm{I}}$ justifies our interpretation of its meaning. To obtain the scale for the relative methyl affinities of aromatic compounds we adopt the following procedure. We define the relative methyl affinity of benzene as unity, and we obtain the relative methyl affinity of any other aromatic compound by dividing the $k_{\mathrm{II}} / k_{\mathrm{I}}$ ratio obtained for such a compound by the $k_{11} / k_{1}$ ratio obtained for benzene. Since the results obtained at $85^{\circ} \mathrm{C}$ are more reproducible and experimentally more accurate, we average them to obtain the desired data. The results of such computations are listed in Table II.

It seems that the methyl affinity increases with increasing conjugation in an aromatic system. This point is well illustrated by the following data. Diphenyl ether represents essentially two nonconjugated benzene rings and its methyl affinity is approximately twice as high as that of benzene. On the other hand, diphenyl and benzophenone exemplified compounds in which the two benzene rings are conjugated, and indeed their methyl affinities are well above the double value of the benzene methyl affinity. The heterocyclic compounds resemble closely their isocyclic analogs. The methyl affinity of pyridine is similar to that of benzene, and the methyl affinity of quinoline is close to that of naphthalene.

A full account of this investigation will be published later. We thank the National Science Foundation for the financial support of this study.

* It is still an unsettled problem whether the reaction which involves methyl radicals is caused by "free" methyl radicals, or by acetate radicals which are decarboxylated in the course of the reaction. However, the distinction between these two alternatives is relatively unimportant for our
present problem.

2 W. Magat and R. Bonême, Compt. rend. 232, 1657 (1951). (1953).

${ }^{3}$ E. C. Kooyman and E. Farenhorst, Trans. Faraday Soc. 49, 58 (1953).

4 C. S. Marvel and W. S. Anderson, J. Am. Chem. Soc. 75, 4600 (1953). ${ }^{5}$ F. R. Mayo, J. Am. Chem. Soc. 75, 6133 (1953).

7 My, Steinberg, and Szwarc J. Am. Chem. Soc. 76, 3439 (1954).

$7 \mathrm{M}$. Levy and M. Szwarc. J. Am. Chem. Soc. (to be published).

\section{Microwave Spectrum of Formic Acid* \\ Ralph Trambarulo and Paul M. Moser Department of Physics, University of Delaware.
Newark, Delaware \\ (Received July 2, 1954)}

7 HE rotational spectra of $\mathrm{HCOOH}$ and $\mathrm{HCOOD}$ have been examined in the regions from 21 to 25 and 41 to $50 \mathrm{Kmc}$ with a Stark-modulation spectrometer. Several transitions which have been identified are listed in Table $\mathrm{Y}$. Also given are the theoretical values of the transition frequencies in terms of $B$ and $C$ 